\title{
Antiproliferative Properties and Biomolecular Interactions of Three Novel Pd(II) and Pt(II) Complexes
}

Lara Massai, ${ }^{a}$ Alessandro Pratesi,${ }^{a}$ Jovana Bogojeski, ${ }^{b}$ Marco Banchini, ${ }^{a}$ Serena Pillozzi, ${ }^{c}$ Luigi Messori, ${ }^{a *}$ and Živadin D. Bugarčić ${ }^{b^{*}}$

${ }^{\text {a }}$ Laboratory of Metals in Medicine, Department of Chemistry, University of Florence, via della Lastruccia 3, 50019 Sesto Fiorentino, Florence, Italy

${ }^{\mathrm{b}}$ Department of Chemistry, Faculty of Science, University of Kragujevac, R. Domanovića 12, P. O. Box 60, 34000 Kragujevac, Serbia

${ }^{\mathrm{c}}$ Department of Experimental and Clinical Medicine, University of Florence, Viale G.B. Morgagni 50, Florence, Italy

* Corresponding authors:

Živadin D. Bugarčić

E-mail: bugarcic@kg.ac.rs

L. Messori

E-mail: luigi.messori@unifi.it; 


\begin{abstract}
Three novel Pd(II) and Pt(II) complexes with chelating mono(imidazolin-2-imine) and bis(imidazolin-2imine) ligands i.e. $\left[\mathrm{Pd}\left(\mathrm{DMEAIm}^{\mathrm{iPr}}\right) \mathrm{Cl}_{2}\right](\mathbf{1}),\left[\mathrm{Pd}\left(\mathrm{DACH}\left(\mathrm{Im}^{\mathrm{iPr}}{ }_{2}\right) \mathrm{Cl}_{2}\right](\mathbf{2})\right.$ and $\left[\mathrm{Pt}\left(\mathrm{DMEAIm}^{\mathrm{iPr}}\right) \mathrm{Cl}_{2}\right](\mathbf{3})$, are evaluated here as potential cytotoxic and anticancer agents. An acceptable solution behaviour was found for the three study compounds in terms of solubility and stability. Notably, the three metal complexes demonstrated moderate to high cytotoxic properties in two selected cancer cell lines i.e. FLG 29.1 and HCT-116. To gain deeper mechanistic insight, the reactivity of the study complexes with model DNA oligos and protein molecules was investigated through spectrometric and spectroscopic methods; in both cases adduct formation was clearly documented by ESI-MS measurements. The binding of these metal complexes to calf thymus DNA (CT-DNA) was further examined by absorption (UV-Vis) and emission spectral studies (EthBr displacement studies). Overall, the studied complexes 1-3 exhibited a remarkable DNA binding ability that might be linked to the observed cytotoxic effects. Interestingly our results revealed that DNA binding, as well as anticancer activity of 1-3 follows the order $\mathbf{2}>\mathbf{3}>\mathbf{1}$. The implications of these findings are discussed.
\end{abstract}

\title{
Keywords
}

CT-DNA; platinum and palladium compounds; anticancer drugs. 


\section{Introduction}

In the early sixties Rosenberg's discovery of the remarkable anti-tumor properties of cisplatin cleared the way to a new field of bioinorganic research, the use of compounds of non-essential metals in medicine and in cancer treatment [1]. Although 40 years have now past from the first approval of cisplatin as a chemotherapeutic agent, this is still one of the most used cytostatics worldwide for the treatment of different types of cancer (ovarian, head, neck, cervical and other cancers) [2-6]. Regardless of the great success of cisplatin, the severe side-effects and the frequent resistance are main drawbacks for its clinical use. Thus, the development of platinum complexes structurally distinct from cisplatin, that can form different types of DNA-Pt adducts, may lead to the discovery of new compounds showing a different spectrum of biological activity, complementary to cisplatin, [2-6] hopefully accompanied by a more favourable toxicological profile.

The strict similarity between the coordination chemistry of $\mathrm{Pd}(\mathrm{II})$ and $\mathrm{Pt}(\mathrm{II})$ compounds has triggered a number of studies on $\mathrm{Pd}(\mathrm{II})$ complexes as prospective anti-tumor drugs [7,8]. Coordination compounds of $\mathrm{Pd}(\mathrm{II})$ are suitable models for studying the interaction with different bio-molecules since they react ca. 104-105 times faster than their Pt(II) analogues, whereas their structural and equilibrium behaviour in solution are very similar to those of Pt(II) complexes. Similarly, the hydrolysis of Pd(II) complexes is very rapid e.g. 105 times faster than in the corresponding $\mathrm{Pt}(\mathrm{II})$ analogues. Thus, $\mathrm{Pd}$ complexes dissociate readily in solution leading to formation of very reactive aqua species that are unable to reach their pharmacological targets [7]. However, in recent years, research indicated that some Pd(II) complexes may manifest a biological activity in vitro equal to (or even superior than) cisplatin [9-13]. A substantial progress in the field of anticancer chemistry of palladium-based complexes was achieved through implementation of new synthetic methodologies leading to insertion of bulky aromatic or aliphatic nitrogen ligands, of chiral organic moieties, of chelates containing other donor atoms than nitrogen; multinuclear Pd(II) complexes were also prepared and characterised as well as heterobimetallic complexes [9-13]. Specifically, in this investigation, we have tested a few recent $\mathrm{Pd}(\mathrm{II})$ and $\mathrm{Pt}(\mathrm{II})$ complexes with electron donating and bulky mono- and bis(imidazolin-2-imine) ligands and studied their interactions with DNA and protein models. The cytotoxicity of $\operatorname{Pd}(\mathrm{II})$ and $\mathrm{Pt}(\mathrm{II})$ complexes toward few representative tumor cell lines was explored as well.

The studied complexes are synoptically represented in Figure 1. These compounds always feature a square planar geometry with $\mathrm{Pd}(\mathrm{II})$ or $\mathrm{Pt}(\mathrm{II})$ as central metals. These metal complexes were previously prepared and characterized [14]. In all cases the metal is bound to two nitrogen donors and two chloride donors. Interestingly, compound $\mathbf{2}$ and compound $\mathbf{3}$ are structurally related to compound 
1. While in complex $\mathbf{1}$ the two nitrogen donors are different in nature, in complex 2 the two nitrogen donors bear identical substituents. At variance, in complex $3 \mathrm{Pd}(\mathrm{II})$ is directly replaced by a platinum(II) center.

[insert figure 1]

\section{Materials and methods}

\subsection{General}

The complexes $\left[\mathrm{Pd}\left(\mathrm{DMEAIm}^{\mathrm{iPr}}\right) \mathrm{Cl}_{2}\right](\mathbf{1}),\left[\mathrm{Pd}\left(\mathrm{DACH}\left(\operatorname{Im}^{\mathrm{iPr}}\right)_{2}\right) \mathrm{Cl}_{2}\right](\mathbf{2})$ and $\left[\operatorname{Pt}\left(\mathrm{DMEAIm}^{\mathrm{iPr}}\right) \mathrm{Cl}_{2}\right]$ (3) were synthesized as reported previously. [14] The purity of the complexes were evaluated by IR, elemental analysis and NMR spectroscopy. Horse heart cytochrome c (C7752), ribonuclease A from bovine pancreas type XII-A (RNase 055K7695), ODN4, as well as all the chemicals for the various buffer solution were purchased from Sigma. All the chemicals proteins, CT-DNA and oligonucleotide were used as received without further purification and the solutions were prepared with deionized water produced by a Millipore system.

\subsection{Stability studies in solution}

$\mathrm{UV}-\mathrm{Vis}$ absorption spectra were recorded on a Varian Cary $50 \mathrm{UV}-\mathrm{Vis}$ spectrophotometer (Varian, Palo Alto, CA, USA) in the range of $200-600 \mathrm{~nm}$. Stock solution of 1-3 $\left(10^{-3} \mathrm{M}\right)$ was prepared by dissolving the complex under investigation in buffer (PB or PBS). For stability studies in solution, UV-Vis measurements were performed by diluting the compound's stock solutions to $3 \times 10^{-5} \mathrm{M}$ in the selected buffer. Spectra were collected during $48 \mathrm{~h}$ at room temperature, operating in 10 min intervals during the first hour and in $1 \mathrm{~h}$ intervals afterward.

\subsection{UV-Vis DNA interactions}

A stock solution of CT-DNA was prepared in PBS buffer, which gave a ratio of UV absorbances at $260 \mathrm{~nm}$ and $280 \mathrm{~nm}$ (A260/A280) of ca. 1.8-1.9, indicating that the DNA was sufficiently free of protein and the concentration was determined by the UV absorbance at $260 \mathrm{~nm}\left(\varepsilon=6600 \mathrm{M}^{-1} \mathrm{~cm}^{-1}\right)$ [15].

The UV-Vis spectra were obtained on a Perkin-Elmer Lambda 35 or 25 double beam spectrophotometer, using $1.0 \mathrm{~cm}$ path-length quartz cuvettes $(3.0 \mathrm{~mL})$. Fluorescence measurements were run on a RF-1501 PC spectrofluorometer (Shimadzu, Japan). The fluorescence spectra were recorded in the range $550-750 \mathrm{~nm}$ upon excitation at $527 \mathrm{~nm}$ in all cases. The excitation and emission 
bandwidths were both $10 \mathrm{~nm}$.

\subsection{UV-Vis absorption studies}

In order to compare quantitatively the binding strength of the complexes, the intrinsic binding constants $\mathrm{K}_{\mathrm{b}}$ were determined by monitoring the changes in absorption at the MLCT band with increasing concentration of CT-DNA using the following Equation 1.

$$
[\mathrm{DNA}] /\left(\varepsilon_{\mathrm{A}}-\varepsilon_{\mathrm{f}}\right)=[\mathrm{DNA}] /\left(\varepsilon_{\mathrm{b}}-\varepsilon_{\mathrm{f}}\right)+1 /\left[\mathrm{K}_{\mathrm{b}}\left(\varepsilon_{\mathrm{b}}-\varepsilon_{\mathrm{f}}\right)\right] \text { Equation } 1 \text {. }
$$

$\mathrm{Kb}$ is given by the ratio of slope to the $\mathrm{y}$ intercept in plots $[\mathrm{DNA}] /\left(\varepsilon_{\mathrm{A}}-\varepsilon_{\mathrm{f}}\right)$ versus [DNA] (Figure 4, S8 and S9), where [DNA] is the concentration of DNA in base pairs, $\varepsilon_{\mathrm{A}} \mathrm{A}_{\mathrm{obsd}} /\left[\right.$ complex], $\varepsilon_{\mathrm{f}}$ is the extinction coefficient for the unbound complex and $\varepsilon b$ is the extinction coefficient for the complex in the fully bound form.

\subsection{Ethidium bromide (EthBr) displacement studies}

The relative binding of complexes to CT-DNA was determined by calculating the quenching constant (Ksv) from the slopes of straight lines obtained from Stern-Volmer equation (Equation 2).

$$
\mathrm{I}_{0} / \mathrm{I}=1+\mathrm{K}_{\mathrm{sv}}[\mathrm{Q}] \quad \text { Equation } 2 .
$$

$\mathrm{I}_{0}$ and $\mathrm{I}$ are the emission intensities in the absence and the presence of the quencher (complexes 1-3), respectively, [Q] is the total concentration of quencher, $\mathrm{K}_{\mathrm{sv}}$ is the Stern-Volmer quenching constant which can be obtained from the slope of the plot of $\mathrm{I}_{0} / \mathrm{I}$ versus [Q] (Figure 5, S10 and S11).

\subsection{Sample preparation and ESI-MS analysis}

Metal complex/protein and metal complex/oligonucleotide adducts were prepared by adding the selected metal complex dissolved in buffer to the solution of proteins $\left(10^{-4} \mathrm{M}\right)$ in $20 \mathrm{mM}$ ammonium acetate buffer, $\mathrm{pH}$ 6.8. The final metal complex/protein ratio was 3:1. The solutions were incubated for $24 \mathrm{~h}$ at $37^{\circ} \mathrm{C}$. After a 20 -fold dilution with water, ESI-MS spectra were recorded by direct introduction of the sample at a flow rate of $5 \mu \mathrm{L} / \mathrm{min}$ in an LTQ Orbitrap high-resolution mass spectrometer (Thermo, San Jose, CA, USA), equipped with a conventional ESI source. The working conditions were the following: spray voltage $3.1 \mathrm{kV}$, capillary voltage $45 \mathrm{~V}$ and capillary temperature $220{ }^{\circ} \mathrm{C}$. The sheath and the auxiliary gases were set, respectively, at 17 (arbitrary units) and 1 (arbitrary units). Xcalibur 2.0 software (Thermo) was used for acquisition, and monoisotopic and average deconvoluted 
masses were obtained by using the integrated Xtract tool. For spectrum acquisition a nominal resolution (at $m / z 400$ ) of 100,000 was used.

\subsection{Biological studies}

Cell cultures. HCT-116 and FLG 29.1 were cultured in RPMI 1640 (Euroclone; Milan, Italy) with 10\% Fetal Bovine Serum (FBS) (Euroclone Defined; Euroclone; Milan, Italy). We cultured the cell lines at $37{ }^{\circ} \mathrm{C}$ under a humidified atmosphere in $5 \% \mathrm{CO}_{2}$ in air.

Pharmacology experiments. Cells were seeded in a 96-well flat-bottomed plate (Corning-Costar, Corning, NY, USA) at a cell density of $10^{4}$ cells per well in either RPMI or DMEM complete medium. The compounds 1-3 were used, after solubilisation in water with DMSO, in range of concentration of 0-200 nM. After $24 \mathrm{~h}$ and $48 \mathrm{~h}$, viable cells (determined by Trypan blue exclusion) were counted in triplicate using a haemocytometer. Each experimental point represents the mean of a single experiment carried out in triplicate.

Trypan blue assay. Cells viability was assessed by the Trypan blue exclusion assay. In brief, $10 \mu \mathrm{L}$ of $0.4 \%$ trypan blue solution was added to $10 \mu \mathrm{L}$ cell suspensions in culture medium. The suspension was gently mixed and transferred to a haemocytometer. Viable and dead cells were identified and counted under a light microscope. Blue cells failing to exclude the dyes were considered nonviable, and transparent cells were considered viable. The percentage of viable cells was calculated on the basis of the total number of cells (viable plus nonviable).

The $\mathrm{IC}_{50}$ value (i.e., the dose that caused apoptosis of $50 \%$ of cells) was calculated by fitting the data points (after $24 \mathrm{~h}$ and $48 \mathrm{~h}$ of incubation) with a sigmoidal curve using Calcusyn software (Biosoft, Cambridge, UK).

\section{Results and Discussion}

\subsection{Solution behaviour}

The stability and the behaviour of the three complexes in solution were then investigated through UV-Vis spectrophotometric techniques. The electronic spectra were recorded upon diluting small amounts of freshly prepared concentrated solutions of the study complexes in the reference buffer (10 $\mathrm{mM}$ PB, pH 7.4 or $10 \mathrm{mM}$ PBS, pH 7.4). The concentration of each compound in the final sample was $30 \mu \mathrm{M}$. The resulting solutions were monitored by collecting the electronic spectra over $48 \mathrm{~h}$ at room temperature, at regular intervals. In Figure 2 the UV-Vis spectra recorded for a solution of complex 2 in PB are reported. Comparable behaviours in solution were found also for complex $\mathbf{1}$ and $\mathbf{3}$ (see Figure S1-S5). 
[Insert figure 2]

From Figure 2 it emerges that compound 2 manifests some minor time dependent alterations in the long-wave band in PB. In particular, a slight increment in absorbance is present in the range 280-310 $\mathrm{nm}$ and a blue shift of the maximum at $320 \mathrm{~nm}$ is also evident. These spectral changes may be ascribed to partial detachment of the weak chlorido ligands from the metal coordination sphere. Nevertheless, under the given conditions, the hydrolysis process seems to be slow. These results suggest the release of chloride ligands from the complex in aqueous solution as a part of their biological mode of action. As confirmation of this hypothesis, UV-Vis spectra of the same Pd(II) complex (2) were recorded in $\mathrm{PB}$ solution containing $\mathrm{AgNO}_{3} 3 \times 10^{-5} \mathrm{M}$ (Figure 3; S6 and S7).

[Insert figure 3]

From inspection of Figure 3, it clearly emerges that the loss of chloride ligands induced by $\mathrm{AgNO}_{3}$ leads to small/moderate spectral changes very similar to those observed in Figure 2. This result is in good agreement with the hypothesis of partial loss of chloride ligands and can partially explain the relative instability of $\mathbf{2}$ in solution over several hours in terms of progressive chloride release. On the contrary, solutions of complexes 1-3 in PBS appeared to be more stable, probably because of the presence of a higher chloride concentration in solution that inhibited the release of chloride from the complexes (Figure S2, S3 and S5).

\subsection{Antiproliferative properties}

The cytotoxic effects of complexes 1-3 were then assayed by monitoring their ability to inhibit cell growth using the trypan blue assay (see the Experimental section). The antiproliferative activity of the various compounds was first determined in human cancer cells FLG 29.1 (bone marrow-derived preosteoclast cell line of human origin) taken as model of a liquid tumor and in HCT-116 cancer cells (human colon carcinoma), representative for a classical solid tumor. Only complex 2 showed a notable cytotoxic behaviour against the FLG 29.1 cell line with a truly low $\mathrm{IC}_{50}$ value. In the other cases only moderate cytotoxic effects were detected with $\mathrm{IC}_{50}$ values ranging from 17 to $72 \mu \mathrm{M}$. Results are summarized in Table 1.

[Insert table 1] 


\subsection{DNA Interactions}

\subsubsection{UV-Vis absorption studies}

The interactions of the three complexes i.e. $\left[\mathrm{Pd}\left(\mathrm{DMEAIm}^{\mathrm{iPr}}\right) \mathrm{Cl}_{2}\right](\mathbf{1}),\left[\mathrm{Pd}\left(\mathrm{DACH}\left(\mathrm{Im}^{\mathrm{iPr}}\right)_{2}\right) \mathrm{Cl}_{2}\right](\mathbf{2})$ and $\left[\mathrm{Pt}\left(\mathrm{DMEAIm}{ }^{\mathrm{iPr}}\right) \mathrm{Cl}_{2}\right.$ ] (3) with CT-DNA were then studied a by UV-Vis spectrophotometry to determine intrinsic equilibrium binding constants $(\mathrm{Kb})$. Therefore, the metal complex absorption titration studies were carried out at room temperature using fixed concentration of complexes 1-3 (66.7 $\mu \mathrm{M})$ in PBS buffer, and varying the amount of DNA (0-106 $\mu \mathrm{M})$ [16]. In all three studied systems addition of CT-DNA to a solution of 1-3 resulted in a significant hyperchromic effect and red shift for bands between at 200-240 $\mathrm{nm}$ with the appearance of a new band at 258 or $257 \mathrm{~nm}$ (Figure 4, S8 and S9). Significant hyperchromic shift with the appearance of a new signal in UV-Vis spectra clearly suggested a strong interaction between the complexes and CT-DNA through external contacts, presumably hydrogen bonding and electrostatic interactions [17]. Also, the significant red shift may be associated with the involvement of aromatic chromophores of DNA, suggesting the presence of combined covalent (N7 coordination) and non-covalent intercalative binding of the complex to DNA.

[Insert table 2]

[Insert figure 4]

\subsubsection{Ethidium bromide (EthBr) displacement studies}

Interaction of complexes 1-3 with CT-DNA was also investigated by EthBr displacement studies, which provide strong evidence for competitive binding of drugs with CT-DNA. EthBr is nonfluorescent in nature, while its complex with CT-DNA shows strong emission due to its good intercalation ability in DNA double helix. Interaction of complexes 1-3 with CT-DNA led to significant quenching in fluorescence intensity due to the displacement of EthBr from EthBr-DNA complex. The quenching parameters for 1-3 have been calculated using Stern-Volmer equation. Therefore, EthBr displacement studies were performed by changing the concentration of metal complexes and monitoring the emission intensity of EthBr-DNA complex. [15] An increase in the concentration of 1$3(0-25 \mu \mathrm{M})$ caused a significant decrease in fluorescence intensity with a noticeable red shift (Figure 5, S10 and S11). This suggests that EthBr is released from EthBr-DNA complex due to its exchange with studied complexes. Thus, complexes 1-3 are capable of displacing EthBr from EthBr-DNA complex and of interacting strongly with DNA binding sites. [18]

[Insert figure 5] 
The results presented in Table 2 support a tight interaction of the study complexes with CT-DNA. The binding affinity of the complexes toward CT-DNA follows the order $\mathbf{2}>\mathbf{3}>\mathbf{1}$, as highlighted in Table 2. Moreover, these results imply that EthBr displacement efficiency of $\mathbf{2}$ is greater than other complexes and follows the order $\mathbf{2}>\mathbf{3}>\mathbf{1}$. The results are in excellent agreement with the UV-Vis spectral data, demonstrating that all these metal complexes interact with CT-DNA. It is interesting to notice that one of the $\mathrm{Pd}(\mathrm{II})$ complexes, $\left[\mathrm{Pd}\left(\mathrm{DACH}\left(\mathrm{Im}^{\mathrm{iPr}}\right)_{2}\right) \mathrm{Cl}_{2}\right](\mathbf{2})$, shows better interaction with CT-DNA than its $\mathrm{Pt}(\mathrm{II})$ counterpart, $\left[\mathrm{Pt}\left(\mathrm{DMEAIm}{ }^{\mathrm{iPr}}\right) \mathrm{Cl}_{2}\right](3)$. This is in agreement with results from cytotoxicity studies, showing that only complex 2 manifest strong cytotoxic activity against FLG 29.1 cell line.

\subsubsection{ESI-MS experiments}

As completion of the studies related to the understanding of the behaviour of these complexes toward DNA, the interaction of 2 with the oligonucleotide ODN4 (5'CGCGCG3') was also tested, and the ESI-MS spectrum recorded in the negative mode (Figure 6).

For sake of clarity, in all the ESI-MS spectra complex $\mathbf{2}$ is indicated but, for the mass calculation, we referred to the complex 2 deprived of the two chloride residues.

Although the most intense peak corresponds to the triple-charged unreacted ODN4 $(\mathrm{m} / z$ 596.43), the other peaks point out clearly to a certain reactivity of $\mathbf{2}$ toward this oligonucleotide. In fact, the peaks at $\mathrm{m} / \mathrm{z} 1182.31$ and $\mathrm{m} / \mathrm{z} 787.87$ both correspond to the mono-adduct ODN4-(2), and at $\mathrm{m} / \mathrm{z} 823.50$ the same adduct is present plus a $\mathrm{Pd}(\mathrm{II})$ atom disrobed of its ligands. The signal corresponding to the triplecharged ODN4 bearing a naked Pd(II) atom is also well evidenced at $\mathrm{m} / z$ 631.73.

[Insert figure 6]

\subsection{Protein interactions}

\subsubsection{ESI-MS experiments}

In order to prove the effective ability of these $\mathrm{Pd}(\mathrm{II})$ and $\mathrm{Pt}(\mathrm{II})$ complexes to interact with protein targets, a series of ESI-MS measurements were performed on Pd drug-protein and Pt drug-protein samples. ESI-MS spectra were recorded for complexes 1-3 (Figure S14-S17), but only the results obtained with the most promising one (2) are reported here and commented. Two different model proteins have been incubated with 2 for 24h, Cytochrome c (Figure 7) and Ribonuclease A (Figure 8). Inspection of mass spectrometry results provides evidence for the formation of a variety of $\mathrm{Pd}(\mathrm{II})$ adducts of different nature and in considerable amounts. 
[Insert figure 7]

[Insert figure 8]

In the case of Cyt-c (Figure 7), a large percentage of the protein is observed in its unreacted form. Anyway, some reactivity is witnessed by the presence of a monometalated derivative at $\mathrm{m} / \mathrm{z} 12436.19$, and by the adducts of the protein with one or two molecules of $2(\mathrm{~m} / \mathrm{z} 12932.60$ and 13507.89) also accompanied by the presence, respectively, of one and two naked $\operatorname{Pd}(\mathrm{II})$ atoms $(\mathrm{m} / \mathrm{z} 13037.49$ and 13612.78).

On the contrary, in the case of Ribonuclease A (Figure 8), the reactivity of $\mathbf{2}$ becomes more evident as documented by a cluster of very intense peaks. The higher one, at $m / z 14832.84$, can be assigned to the bis-adduct of 2 with RNase A. The other two peaks are related with the previous one, bearing one and two $\mathrm{Pd}(\mathrm{II})$ atoms respectively $(\mathrm{m} / \mathrm{z} 14935.72$ and 15041.62$)$. The peak corresponding to the monoadduct of 2 and $\mathrm{Pd}(\mathrm{II})$ with RNase A ( $\mathrm{m} / z$ 14257.54) is present and, even if with lower intensity, the signals at $\mathrm{m} / z 14257.54$ and $\mathrm{m} / z 14466.32$ derived from RNase-(2) and RNase-(2)-Pd(II), respectively. Moreover, though of low intensity, a peak falling at $m / z 15405.13$ is representative for formation of a tris-adduct, testifying the high level of interaction of complex 2 with the studied protein.

\section{Conclusions}

In conclusion, we have described and characterized here some of the main chemical, biological and pharmacological properties of the three novel Pd and Pt complexes. Notably, these compounds manifest an appreciable solubility and stability in physiological buffers and are thus suitable for biological and pharmacological testing. Moderate to high cytotoxic properties emerged for all of them toward two representative cancer cell lines. Interactions with DNA and protein models were explored showing that these compounds are able to interact extensively and form stable adducts with both kinds of biomolecules. ESI-MS analysis well detects a number of metallic fragments tightly associated to both nucleic acids and proteins through the probable formation of strong coordinative bonds. This type of biomolecular interaction and damage is likely responsible for the conspicuous cytotoxic properties of the study compounds. Some preliminary correlation was highlighted between the affinity of the study complexes for calf thymus DNA and their respective cytotoxicities. 


\section{Acknowledgments}

The authors gratefully acknowledge financial support from the Ministry of Education, Science and Technological Development Serbia, project No. 172011. LM, AP and LM gratefully acknowledged AIRC IG-16049 and Beneficentia Stiftung for financial support. The authors thanks Elena Michelucci and CISM (Centro di Servizi di Spettrometria di Massa, University of Florence) for the record of the ESI-MS spectra.

\section{Abbreviations}

DMEAImiPr = 2-(1,3-diisopropyl-4,5-dimethylimidazolin-2-imine)ethan-1-dimethylamine DACH(ImiPr)2 = N,N'-(cyclohexane-1,2-diyl)bis(1,3-diisopropyl-4,5-dimethylimidazolin-2-imine)

\section{References}

[1] B. Lippert, Cisplatin: Chemistry and Biochemistry of Leading Antitumor Drugs, Wiley-VCH, Germany (1999) 183-221.

[2] E. Alessio, Bioinorganic Medicinal Chemistry, Wiley-VCH, Weinheim (2011) 1-4.

[3] N.P.E. Barry, P.J. Sadler, Chem. Commun. 49 (2013) 5106-5131.

[4] L. Ronconi, P.J. Sadler, Coord. Chem. Rev. 251 (2007) 1633-1648.

[5] M.A. Jakupec, M. Galanski, V.B. Arion, C.G. Hartinger, B.K. Keppler, Dalton. Trans. 2 (2008) 183-194.

[6] A. Bergamo, G. Sava, Chem. Soc. Rev. 44 (2015) 8818-8835.

[7] Ž. D. Bugarčić, J. Bogojeski and R. van Eldik, Coord. Chem. Rev. 292 (2015) 91-106.

[8] Ž. D. Bugarčić, J. Bogojeski, B. Petrović, S. Hochreuther and R. van Eldik, Dalton Trans. 41 (2012) 12329-12345.

[9] A.S. Abu-Surrah, Cancer Therapy 6 (2008) 1-10.

[10] A. S Abu-Surrah and M. Kettunen, Curr. Med. Chem. 13 (2006) 1337-13357.

[11] E. Gao, C. Liu, M. Zhu, H. Lin, Q. Wu and L. Liu, Anticancer Agents Med Chem. 9 (2009) 356368.

[12] E. Gao, M. Zhu, H. Yin, L. Liu, Q. Wu and Y. Sun, J. Inorg. Biochem. 102 (2008) 1958-1964.

[13] J. J Soldevila-Barreda, P. J Sadler, Curr Opin Chem Biol 25 (2015) 172-183. 
[14] (a) J. Bogojeski, J. Volbeda, M. Freytag, M. Tamm, Ž. D. Bugarčić, Dalton Trans. 44 (2015) 17346-17359; (b) J. Bogojeski, J. Volbeda, M. Freytag, Ž. D. Bugarčić, M. Tamm, New J. Chem. submitted.

[15] K. A. Meadows, F. Liu, J. Sou, B. P. Hudson and D. R. McMillin, Inorg. Chem. 32 (1993) 29192923.

[16] (a) E. C. Long, J. K. Barton, Acc. Chem. Res. 23 (1990) 271-273; (b) R. F. Pasternack, E. J. Gibbs, J. Villafranca, J. Biochem, 22 (1983) 2406-2414.

[17] (a) E. S. Koumousi, M. Zampakou, C. P. Raptopoulou, V. Psycharis, C. M. Beavers, S. J. Teat, G. Psomas, T. C. Stamatatos, Inorg. Chem. 51 (2012) 7699-7710; (b) M. A. Rizvi, M. Zaki, Md. Afzal, M. Mane, M. Kumar, B. A. Shah, S. Srivastav, S. Srikrishna, G. M. Peerzada, S. Tabassum, Eur. J. Med. Chem. 90 (2015) 876-888.

[18] (a) F. J. Meyer-Almes, D. Porschke, Biochem 32 (1993) 4246-4253; (b) Z. C. Liu, B. D. Wang, Z. Y. Yang, Y. Li, D. D. Qin, T. R. Li, Eur. J. Med. Chem. 44 (2009) 4477-4484; (c) G. M. Howe, K. C. Wu, W. R. Bauer, Biochem. 19 (1976) 339-347. 
Table 1.

$\mathrm{IC}_{50}$ values $(\mu \mathrm{M})$ of $\mathbf{1 - 3}$ complexes in two representative cancer cell lines.

\begin{tabular}{|l|c|c|}
\hline \multirow{2}{*}{ Compound } & FLG 29.1 & HCT-116 \\
\cline { 2 - 3 } & IC $_{\mathbf{5 0}}$ & IC $_{\mathbf{5 0}}$ \\
\hline$\left[\mathrm{Pd}\left(\mathrm{DMEAIm}^{\mathrm{iPr}}\right) \mathrm{Cl}_{2}\right](\mathbf{1})$ & $27.47 \pm 2.23$ & $71.96 \pm 3.12$ \\
\hline$\left[\mathrm{Pd}\left(\mathrm{DACH}\left(\mathrm{Im}^{\mathrm{iPr}}\right)_{2}\right) \mathrm{Cl}_{2}\right](\mathbf{2})$ & $2.33 \pm 0.06$ & $42.67 \pm 2.54$ \\
\hline$\left[\mathrm{Pt}\left(\mathrm{DMEAIm}{ }^{\mathrm{PPr}}\right) \mathrm{Cl}_{2}\right](\mathbf{3})$ & $17.33 \pm 8.98$ & $72.74 \pm 2.92$ \\
\hline
\end{tabular}

FLG 29.1: bone marrow-derived preosteoclast cell line of human origin; HCT-116: human colon cancer cells.

Table 2.

The DNA-binding constants $(\mathrm{Kb})$ and Stern-Volmer constants (Ksv) for complexes 1-3.

\begin{tabular}{|l|c|c|}
\hline & $\mathbf{K}_{\mathbf{b}}\left[\mathbf{M}^{-1}\right]$ & $\mathbf{K}_{\text {sv }}\left[\mathbf{M}^{-1}\right]$ \\
\hline$\left[\mathrm{Pd}\left(\mathrm{DMEAIm}^{\mathrm{iPr}}\right) \mathrm{Cl}_{2}\right](\mathbf{1})$ & $(1.0 \pm 0.1) \times 10^{4}$ & $(1.6 \pm 0.1) \times 10^{4}$ \\
\hline$\left[\mathrm{Pd}\left(\mathrm{DACH}\left(\mathrm{Im}^{\mathrm{iPr}}\right)_{2}\right) \mathrm{Cl}_{2}\right](\mathbf{2})$ & $(2.0 \pm 0.2) \times 10^{4}$ & $(2.3 \pm 0.1) \times 10^{4}$ \\
\hline$\left[\mathrm{Pt}\left(\mathrm{DMEAIm}{ }^{\mathrm{iPr}}\right) \mathrm{Cl}_{2}\right](\mathbf{3})$ & $(1.2 \pm 0.1) \times 10^{4}$ & $(1.7 \pm 0.1) \times 10^{4}$ \\
\hline
\end{tabular}




\section{CAPTION TO THE FIGURES}

Fig. 1. Structures of the investigated Pd(II) and Pt(II) complexes.

Fig. 2. Time-dependent UV-Vis spectra (up to $48 \mathrm{~h}$ ) of complex $2,3 \times 10^{-5} \mathrm{M}$ dissolved in $10 \mathrm{mM}$ phosphate buffer, $\mathrm{pH} 7.4$.

Fig. 3. Time-dependent UV-Vis spectra (up to $24 \mathrm{~h}$ ) of complex $2,3 \times 10^{-5} \mathrm{M}$ dissolved in $10 \mathrm{mM}$ phosphate buffer, pH 7.4 and $\mathrm{AgNO}_{3} 3 \times 10^{-5} \mathrm{M}$.

Fig. 4. UV-Vis titration spectra of complex $2(66.7 \mu \mathrm{M})$ in PBS buffer with increasing concentration of CT-DNA (0-106 $\mu \mathrm{M})$. Arrow shows hyperchromism in the spectral band. Left graph: plots of $[\mathrm{DNA}] /(\varepsilon \mathrm{A}-\varepsilon f) v s$. [DNA] for the complexes 2.

Fig. 5. Fluorescence titration spectra of EthBr-DNA and of EthBr $(15 \mu \mathrm{M})$ bound to DNA $(15 \mu \mathrm{M})$ in the presence of varying amounts of complex 2. [Arrow shows changes in fluorescence intensity upon increasing concentration of $2(0-25 \mu \mathrm{M})]$. Left graph: Stern-Volmer plots for EthBr-DNA fluorescence titration with 2.

Fig. 6. ESI-MS spectrum of ODN4 in MilliQ water, in presence of 2, after $24 \mathrm{~h}$ incubation at $37{ }^{\circ} \mathrm{C}$. The oligonucleotide concentration was $10^{-4} \mathrm{M}$ (with 3:1 complex to protein molar ratio).

Fig. 7. Deconvoluted ESI-MS spectrum of Cytochrome c in $20 \mathrm{mM}$ ammonium acetate buffer, $\mathrm{pH}$ 6.8 in presence of 2 , after $24 \mathrm{~h}$ incubation at $37^{\circ} \mathrm{C}$. The protein concentration was $10^{-4} \mathrm{M}$ (with $3: 1$ complex to protein molar ratio).

Fig. 8. Deconvoluted ESI-MS spectrum of RNase A in $20 \mathrm{mM}$ ammonium acetate buffer, $\mathrm{pH} 6.8$ in presence of 2 , after $24 \mathrm{~h}$ incubation at $37^{\circ} \mathrm{C}$. The protein concentration was $10^{-4} \mathrm{M}$ (with $3: 1$ complex to protein molar ratio). 
<smiles></smiles>

$\left[\mathrm{Pd}\left(\mathrm{DMEAIm}{ }^{i \mathrm{Pr}}\right) \mathrm{Cl}_{2}\right]$ (1)

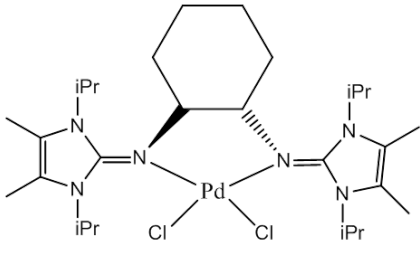

$\left[\mathrm{Pd}\left(\mathrm{DACH}\left(\mathrm{Im}^{i \mathrm{Pr}}\right)_{2}\right) \mathrm{Cl}_{2}\right]$ (2)

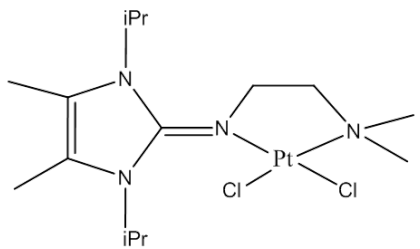

[Pt(DMEAlm $\left.\left.{ }^{i P r}\right) \mathrm{Cl}_{2}\right]$ (3)

Figure 1.

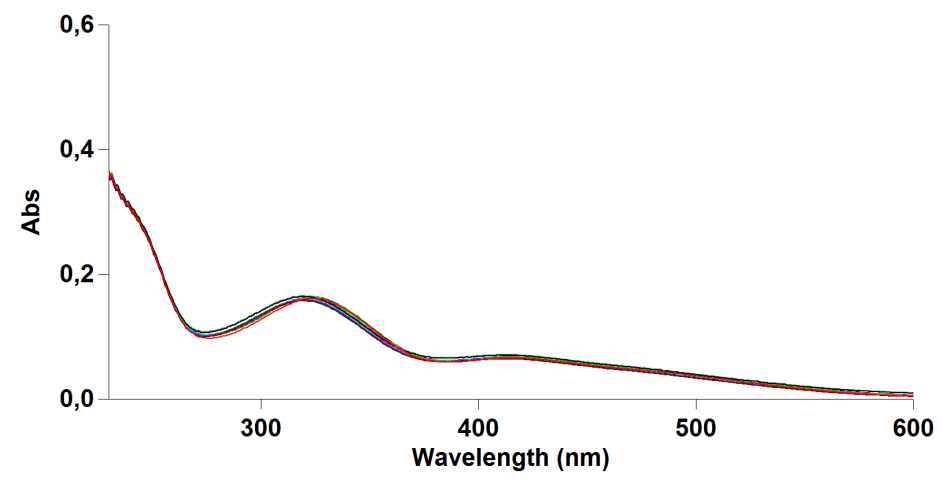

Figure 2.

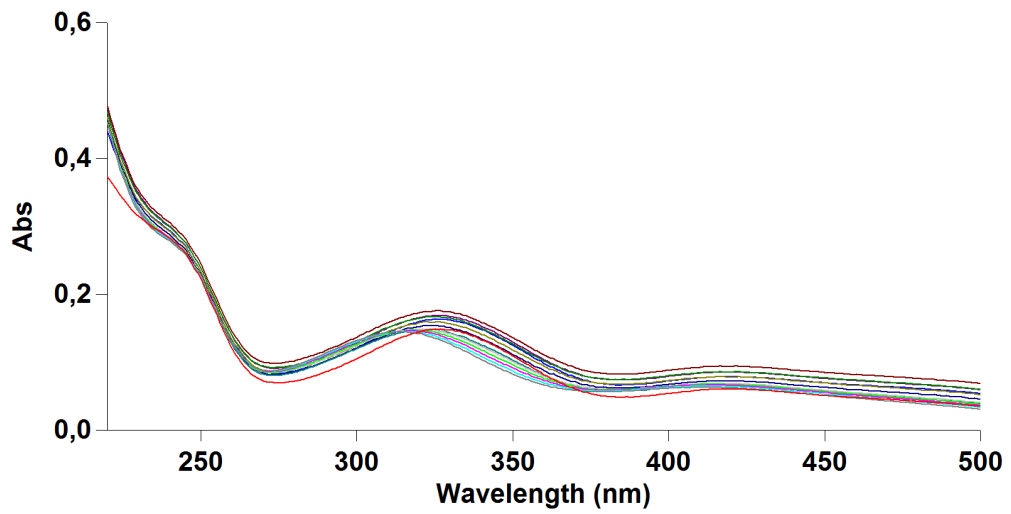

Figure 3. 

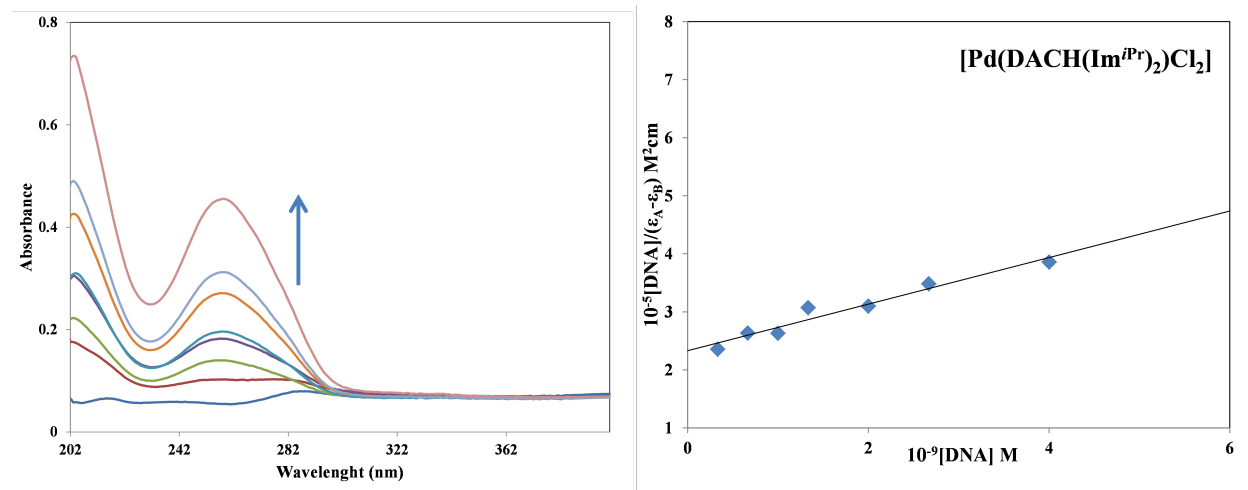

Figure 4.
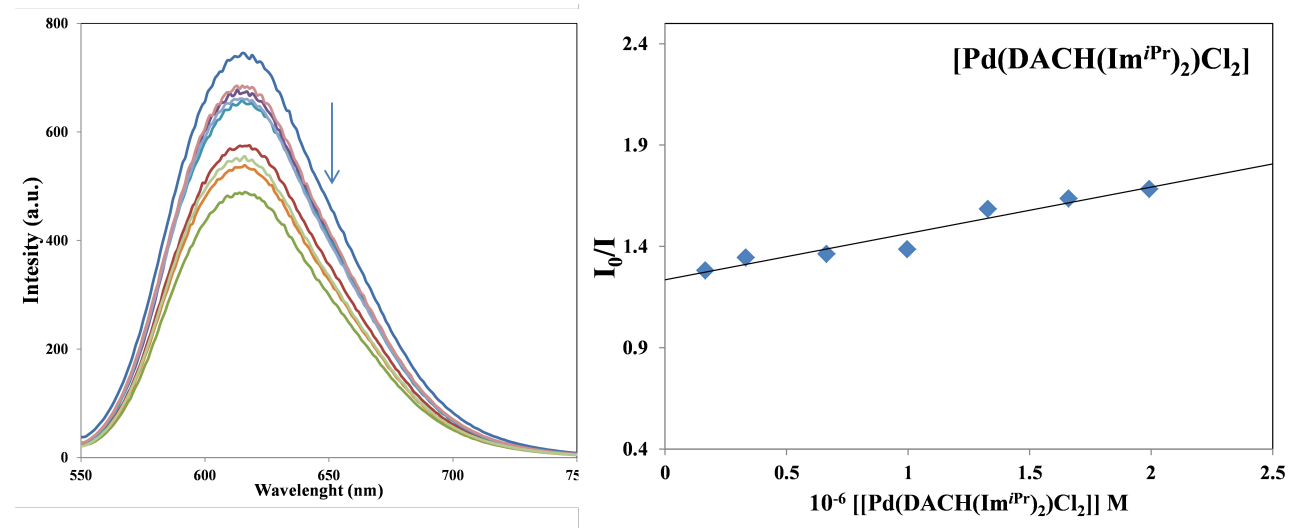

Figure 5.

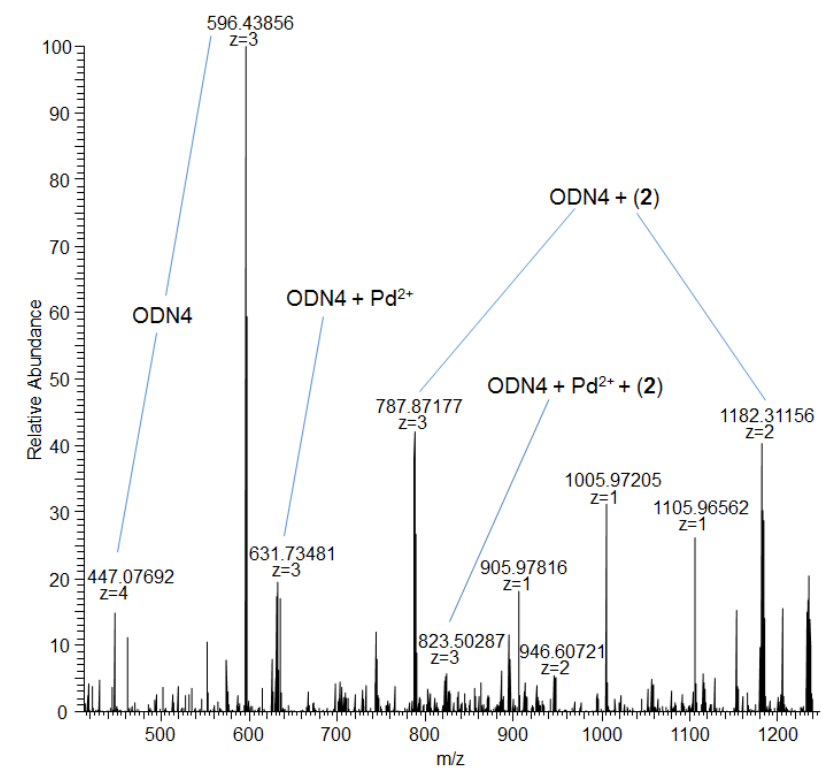

Figure 6. 


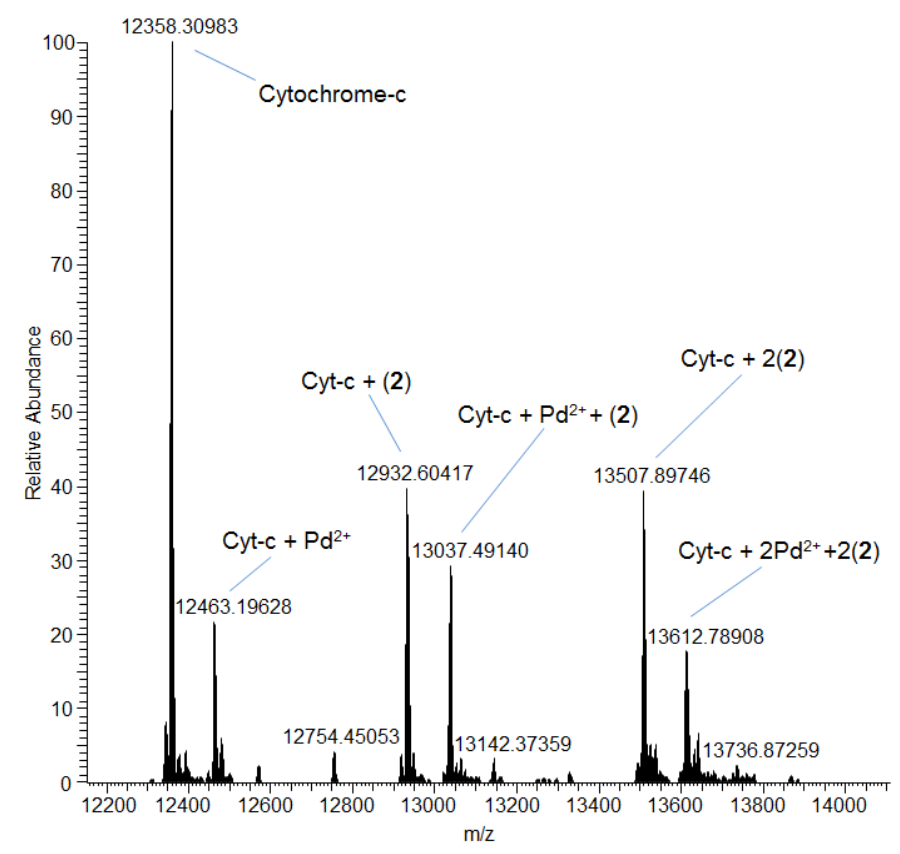

Figure 7.

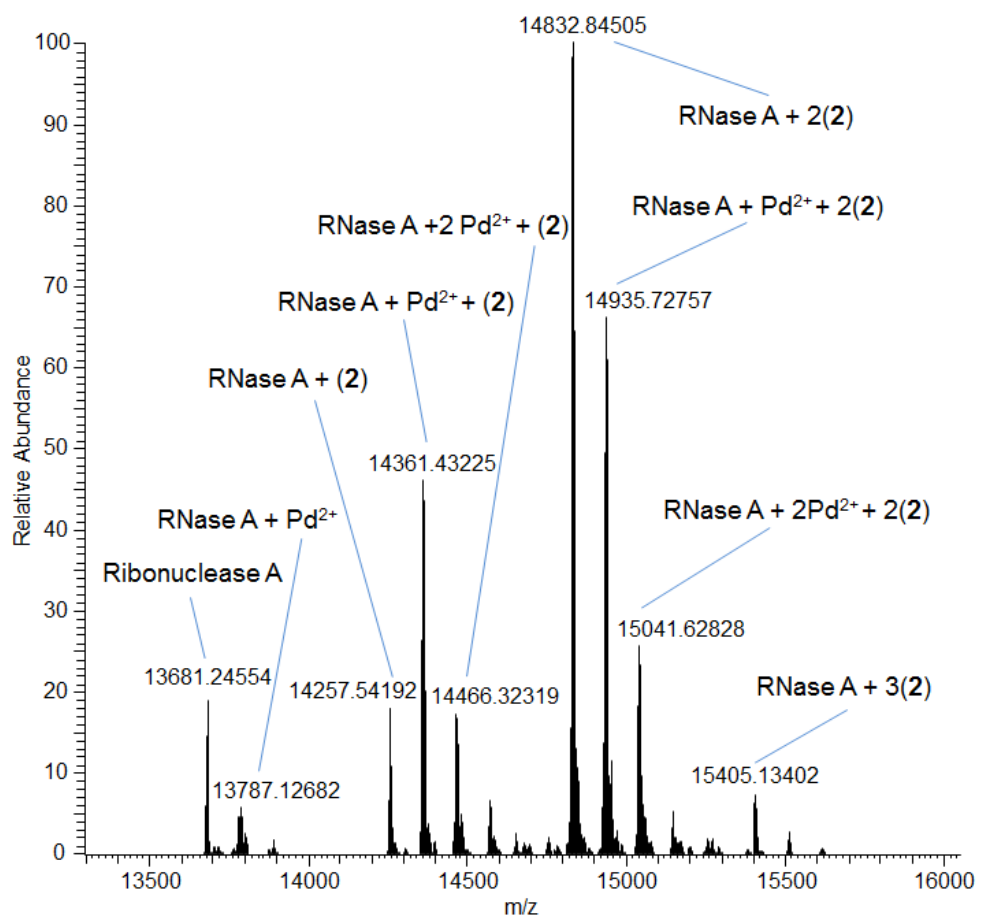

Figure 8 . 